\title{
Sensory Analysis of Pawpaw (Asimina triloba) Pulp Puree: Consumer Appraisal and Descriptive Lexicon
}

\author{
Robert G. Brannan (Corresponding author) \\ School of Applied Health Sciences and Wellness, Ohio University \\ E334 Grover Center, Athens, OH 45701, USA \\ Tel: 1-740-593-2879 E-mail: brannan@ohio.edu
}

Dane E. Salabak

Federal Hocking High School

8461 State Route. 144, Stewart, OH 45778, USA

Tel: 1-740-662-6691Ｅ-mail: dsalabak@fedhock.com

David H. Holben

School of Applied Health Sciences and Wellness, Ohio University

E334 Grover Center, Athens, OH 45701, USA

Tel: 1-740-593-2875 E-mail: holben@ohio.edu

\author{
Received: December 5, 2011 Accepted: December 16, $2011 \quad$ Published: February 1, 2012 \\ doi:10.5539/jfr.v1n1p179 \\ URL: http://dx.doi.org/10.5539/jfr.v1n1p179
}

\begin{abstract}
Consumer and descriptive sensory analysis was performed on pawpaw pulp. Consumer sensory analysis showed that mango was preferred compared to the pawpaw, but that only one-third of those who preferred the mango were correctly able to identify it. Consumers generated 25 flavor descriptors for pawpaw pulp, with banana and mango being the most identified. Descriptive sensory analysis was performed on pawpaw pulp that was stored frozen in the presence or absence of air and with and without heat treatment. Differences in color were detected, however no differences in any of the sensory attributes were detected during 12 months of frozen storage, suggesting that the flavor of pawpaw pulp is stable during frozen storage. The comprehensive analysis of the sensory and quality of pawpaw pulp described in this paper, including the development of a defined, standardized pawpaw sensory lexicon, is an important step in the evolution of pawpaw research.
\end{abstract}

Keywords: Pawpaw, Consumer sensory analysis, Descriptive sensory analysis

\section{Introduction}

Pawpaw [Asimina triloba (L.) Dunal] fruit grow on large trees in the eastern United States in a range that covers parts of northern Florida to southern Ontario and as far west as Nebraska, (K. W. Pomper, Layne, \& Peterson, 1999), an area that comprises all of Appalachia. Among the families in the order Magnoliales, the pawpaw belongs to the Annonaceae family, the tropical custard-apple family. All but one of the 130 genera of the Annonaceae family thrives in the tropical region. Only the genus Asimina grows in the temperate climate zone (Callaway, 1993), specifically the USDA growing zone 5 (Pomper, Layne, \& Peterson, 1999).

Pawpaws are climacteric fruits. Ethylene and respiratory climacteric peaks are clearly evident in the pawpaw within 3 days after harvest (Archbold \& Pomper, 2003). Depending on the ripeness of the pawpaw when it is picked, the ultimate quality of the ripe fruit can be determined (McGrath \& Karahadian, 1994b). Additionally, it has been found that the pawpaw will go from ripe to overripe in a matter of days at room temperature, however this process can be extended to 2-3 weeks while under refrigeration (Templeton, Marlette, Pomper, \& Jones, 2003). Because of the limitations in their perishability, pawpaws are not commonly seen in processing or fresh markets. Ripening pawpaws have shown an increase in soluble solids concentration (exceeding 20\%), softening 
of the flesh, increased production of volatiles, and some genotypes have demonstrated a decline in green color (McGrath \& Karahadian, 1994b). The volatiles produced during ripening are mostly ethyl and methyl esters (Shiota, 1991). Most researchers believe that color change cannot be accepted as a reliable indicator of pawpaw fruit ripeness because varying findings have been reported.

Research suggests that pawpaw fruit pulp has the potential to be added to various consumer goods to add increased nutritional benefits or flavor enhancement. The intense, tropical-fruit-like flavor makes it a potential source of natural fruit flavor (McGrath \& Karahadian, 1994a). Sensory analysis on various pawpaw products at the 2nd Annual Pawpaw Field Day at Kentucky State University (KSU) in Frankfort in 1999, using 105 untrained sensory participants showed that acceptance of products varied by age and previous consumption of pawpaw. Younger participants (under 40) who had not had pawpaw before preferred sweeter products (cake, and ice cream) when compared to custard and juices (Templeton, et al., 2003). Previous researchers have utilized the pawpaw as a partial fat-reducing agent in muffins (Duffrin, Holben, \& Bremner, 2001), and shortened cake (Wiese \& Duffrin, 2003).

Consumers' decision to eat fruit depends on personal preference, nutritional properties, and environmental factors. Past studies have demonstrated that education level, gender, age group, and income level can affect frequency and amount of fruit intake. In addition, people with positive beliefs and attitudes towards healthy eating generally have an increased intake of fruits. Familiarity towards a product or fruit can also help or hinder a consumer's purchase (Kamphuis et al., 2006). Many studies mention that sensory characteristics, health considerations, and pleasure-seeking factors are the main reasons humans consume fruit and continue to consume fruit. In an assessment of consumer responses to an off-flavor in fruit juices, it was revealed that taste perception is a significant factor of level of consumption, and that consumption might discontinue if the first taste impression of the fruit is poor (Tuorila \& Cardello, 2002).

From a sensory standpoint, the literature shows a wide range of tastes, aromas, and other descriptors being used to describe the pawpaw. The flesh has a smooth, custard-like texture (Pomper, Crabtree, Lowe, \& Lehman, 2009) that has been described to be reminiscent of an avocado (Kral, 1960). The color of the pulp ranges from creamy white to bright yellow or even shades of orange in color (Pomper, et.al., 1999).

Past research has used untrained sensory panelists to conduct descriptive analysis on pawpaw pulp. A list of descriptors used to describe the fruit consisted of apple, banana, mango, melon, fresh, raw, and top note (Duffrin $\&$ Pomper, 2006). Most commonly, the flesh of the fresh fruit is described as having a tropical aroma and flavor that is often compared to a mixture of mango, banana and pineapple (Duffrin \& Pomper, 2006). However, according to an untrained panel, frozen pawpaw has been described as tasting sour, bitter and resembling melon (Duffrin \& Pomper, 2006). The similarity of aroma and tastes of the pawpaw to other tropical fruits may make it difficult to differentiate (Shiota, 1991). Poor-quality pawpaws have a mushy texture, lack sweetness, have an overly strong flavor, and bittersweet aftertaste, whereas high-qulity pawpaws that have a firm texture, a delicate blend of flavors, and no bitter aftertaste (Duffrin \& Pomper, 2006).

Currently, no standard descriptive lexicon exists for pawpaw and many descriptors for pawpaw involve the use of other tropical fruits, which in themselves may have limited familiarity. The purpose of this study was twofold. Consumers were employed to characterize how well-known pawpaw fruit is and how much it is liked compared to more common tropical fruits (mango, papaya). Then, a descriptive sensory panel developed a descriptive lexicon for pawpaw and used it to monitor changes in pawpaw pulp during frozen storage.

\section{Materials and Methods}

\subsection{Materials}

All food ingredients were purchased from local retailers with the exception of pawpaws. Wild pawpaws from a single tree were donated for the study. This particular pawpaw tree has won two first-place awards and a second-place award in recent years at the "Best Pawpaw Contest" during the yearly Pawpaw Festival in Albany, Ohio, based on weight, appearance, skin surface, aroma, skin thickness, flavor, texture, aftertaste, and number of seeds. Frozen pawpaw pulp for panel training was purchased from a local pawpaw processor (Integration Acres, Inc., Albany, $\mathrm{OH})$.

\subsection{Sample preparation}

The pawpaw pulp from each pawpaw was separated from the skins and seeds by hand. All of the pulp was pooled and divided into $100 \mathrm{~g}$ portions. Once portioned, the pawpaw pulp was placed into randomly selected polyethylene/nylon 27.94-cm bags (FoodSaver, Jarden Corp., Rye, NY) with an oxygen transmission rate of 6.7 $\mathrm{cc} / \mathrm{m}^{2} / 24 \mathrm{~h} / 23^{\circ} \mathrm{C} / 0 \% \mathrm{RH}$. Once the bags were filled, they were either vacuum sealed (vacuum) or sealed without 
attempting to remove air prior to sealing (air). Some of the bags were heat treated (cooked) in boiling water, until they reached an internal temperature of $75^{\circ} \mathrm{C}$. The bags were transferred into frozen storage at $-18{ }^{\circ} \mathrm{C}$. At two month intervals, pawpaw samples were transferred from $-18^{\circ} \mathrm{C}$ to a freezer at $-40^{\circ} \mathrm{C}$ to maintain pawpaw quality until the day that sensory analysis was performed.

\subsection{Sensory analysis}

Sensory testing was performed using protocols approved by the Ohio University Institutional Review Board for the protection of human subjects. Ninety eight participants were recruited for the consumer study. After providing demographic data, each participant evaluated a randomly coded sample of pureed pawpaw pulp. Water was provided. Participants were asked, "Please taste the tropical fruit pulp. Identify as many tropical fruit flavors as you can and write them in the order of their intensity." Room was provided for five responses to this question. For the second set of samples, participants were presented with three cups of pureed fruit (mango, papaya, pawpaw) and asked, "Please taste the three tropical fruit samples on your tray. Rank them in the order of 1 (most liked), 2 (middle), and 3 (least liked). There are no ties. You must rank them 1, 2, 3. Then, guess what each of the tropical fruits are."

A descriptive sensory panel consisting of six trained members was used to identify and evaluate sixteen attributes in previously-frozen pawpaw pulp. After training, two of the panelists chose not to continue participation in the study, so the decision was made to continue the sampling only with the remaining four panelists. Prior to this study, the descriptive sensory panel was trained for 17 hours on recognition of basic tastes, oral perceptions including texture and mouthfeel, and on how to develop a sensory lexicon prior to sampling for research (Mah \& Brannan, 2009). Approximately 26 additional hours were utilized to train the sensory panel on perception of flavors from the complex flavor profile of the pawpaw. Testing using complex solutions, as well as fresh and processed pawpaw pulp was utilized in the training of the panel. The panel used the results from the consumer study (Table 1) as well as aroma descriptors (McGrath \& Karahadian, 1994b) and the "pawpaw flavor wheel" (Duffrin \& Pomper, 2006) from previous studies as the basis for their development of a pawpaw lexicon. Descriptions and anchored references of the pawpaw sensory attributes are shown in Table 2. Room temperature samples $(\sim 30 \mathrm{~g})$ were presented to panelists in small cups. Six randomized samples coded with a randomly generated three-digit number were tested one at a time at each sampling session. Panelists were supplied with a set of standards for each attribute that they could use throughout the tasting session, shown in Table 1, unlimited water and unsalted saltine crackers, and a ballot with a $15-\mathrm{cm}$ line scale anchored with standards.

\subsection{Color analysis}

The CIE L*, a*, and $b^{*}$ values of thawed pawpaw pulp were measured using a Konica BC-10 (Konica Minolta Sensing Americas Inc., Ramsey, NJ). The meter was calibrated against a standard white plate before each use. The lightness $\left(\mathrm{L}^{*}\right)$ and chromaticity coordinates $\left(\mathrm{a}^{*}, \mathrm{~b}^{*}\right)$ were calculated as the mean of three readings.

\subsection{Texture analysis}

Penetrometry tests using a Ta-XT2i Texture Analyzer (Texture Technologies Corp., Scarsdale NY/Stable Micro Systems, Godalming, Surrey, UK) were used to evaluate the texture of the pawpaw pulp by loading $5 \mathrm{~g}$ of sample into a $18 \times 63 \mathrm{~mm}$ glass test tube and penetrating $60 \mathrm{~mm}$ at $5 \mathrm{~mm} / \mathrm{s}$ with a TA-23 $1 / 2$ " Dia $(13 \mathrm{~mm})-1 / 4 \mathrm{R}$ probe. The grams of force required to compress the sample was recorded using Texture Expert software that controlled the texture analyzer.

\subsection{Statistical analysis}

A $7 \times 2 \times 2$ full factorial design was constructed with three factors; month of storage $(0,2,4,6,8,10,12)$, packaging condition (vacuum, air), and heat treatment (raw, cook). The complete design was not replicated due to the scarcity of sample. All statistical analysis was performed using the PASW Statistics 18 (IBM Corporation, Armonk, New York). Means for color and texture were generated from three observations. Means from descriptive sensory analysis for each patty were generated from the individual ratings of the four panelists. Analysis of Variance (ANOVA) was used to analyze differences between treatments and post-hoc means separation was achieved using Duncan's Multiple Range test. Exploratory factor analysis and theoretical fit was used to reduce the dimensionality of the data. Using Cronbach's Alpha, set at 5 percent, some of the 13 competency statements were categorized into a "factor," with varimax (orthogonal) rotations used to validate the factor analysis. Five factors were identified based on a Kaiser criterion of Eigenvalue greater than or equal to 1.0. Attributes with a variance greater than 0.6 were considered to be within a factor and the attribute was then loaded into the corresponding factor. Items below this variance were considered weakly correlated and eliminated, this in turn increased the reliability of the remaining items. 


\section{Results and Discussion}

Pawpaw flavor is often referred to as a combination of banana, mango, papaya, and pineapple, however these flavor descriptors are often reported by tasters who are very familiar with tropical fruit in general and pawpaw in particular. In this study, a consumer sensory test utilized 98 subjects of varying degrees of familiarity with tropical fruit to assess familiarity of tropical flavors and to generate a pawpaw flavor lexicon. The demographics of the subjects in this study skew young and female (Table 3).

\subsection{Tropical fruit flavors in pawpaw pulp}

Table 1 shows consumers' identification of the "tropical" flavors when presented with a sample of pawpaw pulp. Of the 25 flavors in the pawpaw pulp identified by at least one consumer, banana and mango were identified as the most intense flavors by $77 \%$ of the consumers who made a choice and the second most intense flavors by $68 \%$. Other flavors of note are citrus (orange, grapefruit, tangerine), papaya, and pineapple. The flavor "pawpaw" was identified only three times, once as the primary flavor, once as the third most intense flavor, and once as the fifth most intense flavor.

\subsection{Preference of pawpaw compared to mango and papaya}

However, a forced choice test in which consumers ranked their preference among mango, papaya, and pawpaw revealed that mango, papaya, and especially pawpaw flavors may not be very recognizable to consumers. As shown in Table 4, only one-third of consumers who selected mango as their favorite tropical fruit identified it correctly; only one-fourth of consumers who selected papaya as their favorite identified it correctly; and less than one in ten consumers who selected pawpaw as their favorite could identify it correctly. These results invite a different interpretation of Table 1, suggesting that consumers who identify tropical flavors, especially mango and papaya, may not actually be able to identify them.

With respect to preference, Table 3 shows that mango is preferred significantly compared to papaya and pawpaw overall and across most of the demographic classifications in this study. The data shown in Table 4 reinforces this conclusion as seven in ten consumers selected mango as their favorite, $4-5$ fold higher than either papaya or pawpaw. Interestingly, identification of pawpaw seems to increase with increasing age, education, consumption of fruit, and consumption of tropical fruit (Table 3).

\subsection{Descriptive sensory analysis of pawpaw pulp}

Prior to this study, no thorough pawpaw lexicon for descriptive analysis of pawpaw had been generated. In this study, the trained descriptive panel began its lexicon development with three lists: 1) the twenty-five flavors identified by the consumer panel; 2) five aroma descriptors (fruity aroma, cut grass aroma, sweet aroma, melon-like aroma, and fermented aroma) identified by "a group familiar with pawpaw aroma characteristics" as cited by McGrath and Karahadian (1994b); and 3) eight flavor descriptors (apple, banana, mango, melon, citrus, estery, fresh, raw), three texture descriptors (viscosity, surface, body), and five appearance descriptors (viscosity, surface, body, color, intensity) generated by semi-trained students participating in a class project (Duffrin \& Pomper, 2006). Using this as a basis, the panel developed and standardized the pawpaw lexicon that is described in Table 2.

The lexicon is composed of thirteen attributes including color, fermented odor, texture and two mouthfeel descriptors (body, astringency), two basic tastes (sweet, sour), five flavors (banana, melon, mango, papaya, tropical), and two aftertastes (bitter, rindy). A panelist effect was present. It has been reported that a panelist effect is not unusual in a descriptive analysis panel (N'Kouka, Klein, \& Lee, 2004) and that it indicates that panelists may have been using the scales differently for evaluation even though they were anchored to standards. The panelist effect was identified early in training and much emphasis on intensity recognition of the standards in both group and individual settings was performed. Calibration by the individual judges based on reference means for each attribute was also attempted. None of these strategies alleviated the panelist effect from the final analysis.

The lexicon presented in Table 2 includes five attributes for which published sensory standards have been published (Meilgaard, Ceville, \& Carr, 1999). The other attributes were standardized using foods available in the United States with comparable products likely to found in other countries, making the vocabulary universally applicable. The importance of universality of standards is underscored by the fact the recent Third International Pawpaw Conference (September 9-10, 2011) was truly international, with participants from Canada, the Netherlands, and Romania and an international update that included many more pawpaw-growing countries, especially in Europe. 


\subsubsection{Descriptive analysis of the main effect of month of frozen storage}

As shown in Table 5, significant differences were observed during frozen storage of pawpaw pulp for the main effect of month of frozen storage as well as the two- and three-way interactions involving month of frozen storage for color $\left(\mathrm{L}^{*}, \mathrm{a}^{*}, \mathrm{~b}^{*}\right)$. Storage for 12 months produced pawpaw pulp that was measured to be significantly darker (i.e. higher $\mathrm{L}^{*}$ ), redder (i.e. more positive $\mathrm{a}^{*}$ ), and less yellow (i.e. less positive $\mathrm{b}^{*}$ ). Surprisingly, the differences that were observed via instrumental color analysis were not reflected in the sensory analysis, suggesting that the differences probably were slight enough not to be noticed. A discussion of factors that may affect discoloration during pawpaw storage occurs in section 3.3.2 of this paper. None of the sensory attributes were affected by frozen storage over the 12 month storage period.

\subsubsection{Descriptive analysis of the main effects of packaging and heat treatment}

With respect to the main effects of packaging and heat treatment, none of the sensory or color attributes were significantly affected by the presence or absence of air in the package or heat treatment before storage, except for the following exceptions: The samples that were exposed to air were more red (higher $a^{*}$ ) and exhibited more body (i.e. thicker) than vacuum packaged pawpaw pulp. The samples that were not heat treated were more red (higher $\mathrm{a}^{*}$ ) and yellow (higher $\mathrm{b}^{*}$ ) than the heat treated samples. This difference was confirmed by the sensory panel who perceived the samples that were not heat treated to be significantly darker than the heat treated samples.

The two way interactions between packaging and heat treatment were significant for a*, suggesting that a relationship exists between the presence of oxygen and heat treatment. Most likely, this relationship involves the formation of colored pigments via the enzyme polyphenol oxidase, for which oxygen is required and heat would denature. Polyphenol oxidase has been shown to be present in pawpaw pulp (Fang, Wang, Xiong, \& Pomper, 2007; Wang, Fang, Xiong, \& Pomper, 2008) and likely is responsible for discoloration observed during refrigerated storage (Archbold, Koslanund, \& Pomper, 2003). The discoloration of pawpaw pulp due to polyphenol oxidase has not been monitored in pawpaw pulp stored frozen.

\subsection{Three way interactions of month of storage, packaging, and heat treatment}

The three way interactions among month of storage, packaging, and heat treatment produced 28 distinct samples. Means for sensory and quality parameters of these samples are shown in Tables 6-8. Shown in Table 6, significant differences were observed for all three CIE color measurements $\left(L^{*}, a^{*}, b^{*}\right)$. There were few differences with respect to $L^{*}$, however, it is worth noting that within the heat treated/vacuum stored sample set, the $L^{*}$ value significantly increased during the first four months of storage, from 53.8 to 68.9 , then remained constant thereafter. The means of pawpaw pulp for the $\mathrm{a}^{*}$ values were grouped into seventeen post hoc subsets. This very large number of subsets makes comparisons between and among samples difficult to interpret. Once again, the heat treated/vacuum stored sample set exhibited a clear pattern, with $a^{*}$ values decreasing during storage, from 7.0 at 0 month to 4.3 by 8 months of storage. During storage the cooked samples were often, but not always, significantly lower than their uncooked counterparts. The means of pawpaw pulp for the $b^{*}$ values were grouped into 9 post hoc subsets, but other than the fact that the lowest $b^{*}$ values were exhibited by the 12 month air samples, other interpretations of this data are difficult.

Descriptive sensory data for pawpaw flavor, odor, taste, aftertaste, and mouthfeel are shown in Tables 7 and 8 . No significant differences were observed for any of the attributes. This is a surprising result since research from our laboratory has shown that phenolic and flavonoid compounds in pawpaw pulp are affected by frozen storage (Harris \& Brannan, 2009). In spite of this, it appears likely that that the sensory attributes of pawpaw pulp are stable during frozen storage. Although there are no significant differences between any of the 28 three way interactions, the values are included in this paper because this is the first time that standardized descriptive sensory analysis of the pawpaw was undertaken, thus these values serve as a baseline for future research.

\subsection{Principal components analysis of descriptive sensory data}

The raw survey results were subjected to factor analysis and theoretical fit using Varimax rotations (Figure 1). The data was reduced in dimension from 14 sensory descriptors to three factors. These three factors accounted for more than $65 \%$ of the variance. Of the six sweet or "fruity" attributes in the original set, melon, banana, mango, and tropical were loaded into one of the three factors, while sweet and papaya were not. All of the factors contained at least one negative sensory attribute. The first factor, PC1, was composed melon, banana, and astringent. Banana was identified by consumers in Table 1 as the most intense flavor of the pawpaw, and astringency is inversely related to the ripening of banana. PC2 is composed of the competing descriptors of fermented odor and mango. Mango was identified by consumers in Table 1 as the second most intense flavor in 
pawpaw pulp, although Table 4 shows that only $33 \%$ consumers can correctly identify it. Fermented odor is known to exist in pawpaw (Goodrich, Zjhra, Ley, \& Raguso, 2006) and is generally considered a defect. PC3 is composed of sour aftertaste and tropical flavor. The tropical flavor descriptor was not necessarily a positive flavor descriptor in the sense that the standard reference for the attribute was a piece of canned papaya, whereas sourness is an important component of the sweet-acid balance of fruits. Overall, a reduction in the number of attributes via factor analysis may be beneficial for three reasons: 1) a large number of attributes (13) were developed for the pawpaw lexicon, making sensory analysis challenging; 2) a significant panelist effect was observed throughout the duration of training and sampling despite a concerted attempt to minimize it; and 3) fewer attributes will allow more straightforward elucidation of clusters of related terms.

\section{Conclusion}

This paper provides details of a comprehensive analysis of the sensory and quality of pawpaw pulp from a consumer and descriptive sensory perspective. The development of a defined, standardized pawpaw sensory lexicon is an important step in the evolution of pawpaw research which will allow scientific comparison between and among the 80+ known varieties. However, the consumer research yielded results that show that in spite of a standardized lexicon for the pawpaw, many consumers find it challenging to describe tropical fruits in general, even common ones like mango and papaya. This paper suggests that frozen storage may be a viable preservation option for pawpaw pulp and validates a commercial approach that is already being utilized by an entrepreneurial pawpaw processor (Integration Acres, Albany, $\mathrm{OH}$ ). Future research should focus on validating and refining the pawpaw lexicon.

\section{Acknowledgements}

The authors gratefully acknowledge Lisa Dael, Jody Grenert, Doug Grammar, and Chris Sandford for participating as descriptive sensory analysis panelists.

\section{References}

Archbold, D. D., \& Pomper, K. W. (2003). Ripening pawpaw fruit exhibit respiratory and ethylene climacterics. Postharvest Biology And Technology, 30(1), 99-103. http://dx.doi.org/10.1016/S0925-5214(03)00135-2

Archbold, D. D., Koslanund, R., \& Pomper, K. W. (2003). Ripening and postharvest storage of pawpaw. Horttechnology, 13(3), 439-441.

Callaway, M. B. (1993). Pawpaw (Asimina triloba): A "tropical" fruit for temperate climates In J. Janick \& J. E. Simon (Eds.), New Crops (pp. 505-515). Wiley, New York.

Duffrin, M. W., \& Pomper, K. (2006). Development of Flavor Descriptors for Pawpaw Fruit Puree: A Step Toward the Establishment of a Native Tree Fruit Industry. Family and Consumer Sciences Research Journal, 35(2), 1-13. http://dx.doi.org/10.1177/1077727X06292931

Duffrin, M. W., Holben, D. H., \& Bremner, M. J. (2001). Consumer Acceptance of Pawpaw (Asimina Triloba) Fruit Puree as a Fat-Reducing Agent in Muffins, Compared to Muffins Made with Applesauce and Fat. Family and Consumer Sciences Research Journal, 29(3), 281-287. http://dx.doi.org/10.1177/1077727X01293005

Fang, C., Wang, C. Z., Xiong, Y. L. L., \& Pomper, K. W. (2007). Extraction and characterization of polyphenol oxidase in pawpaw (Asimina triloba) fruit. Journal of Food Biochemistry, 31(5), 603-620. http://dx.doi.org/10.1111/j.1745-4514.2007.00133.x

Goodrich, K. R., Zjhra, M. L., Ley, C. A., \& Raguso, R. A. (2006). When flowers smell fermented: The chemistry and ontogeny of yeasty floral scent in pawpaw (Asimina triloba: Annonaceae). International Journal of Plant Sciences, 167(1), 33-46. http://dx.doi.org/10.1086/498351

Harris, G. G., \& Brannan, R. G. (2009). A preliminary evaluation of antioxidant compounds, reducing potential, and radical scavenging of pawpaw (Asimina tribloba) fruit pulp from different stages of ripeness. Lwt-Food Science And Technology, 42(1), 275-279. http://dx.doi.org/10.1016/j.lwt.2008.05.006

Kamphuis, C. B. M., Giskes, K., de Bruijn, G. J., Wendel-Vos, W., Brug, J., \& van Lenthe, F. J. (2006). Environmental determinants of fruit and vegetable consumption among adults: a systematic review. British Journal of Nutrition, 96(4), 620-635.

Kral, R. (1960). A revision of Asimina and Deeringothamus (Annonaceae). Brittonia, 12(4), 233-278. http://dx.doi.org/10.2307/2805119

Mah, E., \& Brannan, R. G. (2009). Reduction of Oil Absorption in Deep-Fried, Battered, and Breaded Chicken Patties Using Whey Protein Isolate as a Postbreading Dip: Effect on Flavor, Color, and Texture. Journal of Food Science, 74(1), S9-S16. http://dx.doi.org/10.1111/j.1750-3841.2008.00973.x 
McGrath, M. J., \& Karahadian, C. (1994a). Evaluation Of Headspace Volatiles And Sensory Characteristics Of Ripe Pawpaws (Asimina-Triloba) From Selected Cultivars. Food Chemistry, 51(3), 255-262. http://dx.doi.org/10.1016/0308-8146(94)90024-8

McGrath, M. J., \& Karahadian, C. (1994b). Evaluation Of Physical, Chemical, And Sensory Properties Of Pawpaw Fruit (Asimina-Triloba) As Indicators Of Ripeness. Journal Of Agricultural And Food Chemistry, 42(4), 968-974. http://dx.doi.org/10.1021/jf00040a025

Meilgaard, M., Ceville, G. V., \& Carr, B. T. (1999). Sensory Evaluation Techniques. Boca Raton: CRC Press. http://dx.doi.org/10.1201/9781439832271

N'Kouka, K. D., Klein, B. P., \& Lee, S. Y. (2004). Developing a lexicon for descriptive analysis of soymilks. Journal of Food Science, 69(7), S259-S263. http://dx.doi.org/10.1111/j.1365-2621.2004.tb13625.x

Pomper, K. W., Crabtree, S., Lowe, J., \& Lehman, J. (2009). Pawpaw and the American Persimmon: Niche Tree Fruit Crops for the Midwest and Eastern United States. Hortscience, 44(4), 982-983.

Pomper, K. W., Layne, D. R., \& Peterson, R. N. (1999). The pawpaw regional variety trial. In J. Janick (Ed.), Perspectives on New Crops and New Uses (pp. 353-357). Alexandria, VA: ASHS Press.

Shiota, H. (1991). Volatile Components Of Pawpaw Fruit (Asimina-Triloba Dunal). Journal of Agricultural And Food Chemistry, 39(9), 1631-1635. http://dx.doi.org/10.1021/jf00009a019

Templeton, S. B., Marlette, M., Pomper, K. W., \& Jones, S. C. (2003). Favorable taste ratings for several pawpaw products. Horttechnology, 13(3), 445-448.

Tuorila, H., \& Cardello, A. V. (2002). Consumer responses to an off-flavor in juice in the presence of specific health claims. Food Quality and Preference, 13(7-8), 561-569. http://dx.doi.org/10.1016/S0950-3293(01)00076-3

Wang, C. Z., Fang, C. D., Xiong, Y. L., \& Pomper, K. (2008). Genotypic variation and heat susceptibility of polyphenol oxidase activity in pawpaw fruit pulp. Hortscience, 43(4), 1212-1212.

Wiese, T. D., \& Duffrin, M. W. (2003). Effects of substituting pawpaw fruit puree for fat on the sensory properties of a plain shortened cake. Horttechnology, 13(3), 442-444.

Table 1. Consumers ( $\mathrm{n}=98)$ free choice identification of tropical fruit flavors when presented pawpaw pulp in the order of their perceived intensity

\begin{tabular}{|l|l|l|l|}
\hline $\begin{array}{l}\text { Identified as Most } \\
\text { Intense Flavor }\end{array}$ & $\begin{array}{l}\text { Identified as 2nd } \\
\text { Intense Flavor }\end{array}$ & $\begin{array}{l}\text { Identified as 3rd Most } \\
\text { Intense Flavor }\end{array}$ & $\begin{array}{l}\text { Identified as 4th Most } \\
\text { Intense Flavor }\end{array}$ \\
\hline Banana (40) & Mango (24) & Mango (10) & Papaya (4) \\
\hline Mango (24) & Banana (13) & Pineapple (9) & Mango (4) \\
\hline Orange (7) & Papaya (8) & Orange (8) & Tangerine (3) \\
\hline Papaya (7) & Orange (7) & Banana (7) & Guava (2) \\
\hline Pineapple (5) & Grapefruit (2) & Papaya (4) & Pineapple (2) \\
\hline Did not identify (15) & Did not identify (44) & Did not identify (60) & Did not identify (83) \\
\hline
\end{tabular}

Number in parenthesis indicates number of consumers who identified the flavor. 
Table 2. Description and anchored references of sensory attributes generated by descriptive analysis of pawpaw pulp

\begin{tabular}{|c|c|c|c|}
\hline Attribute & Description & References & $\begin{array}{l}\text { Position } \\
(\mathrm{cm})^{1}\end{array}$ \\
\hline Color & $\begin{array}{l}\text { Color of the top surface of the pulp, } \\
\text { detected prior to mixing }\end{array}$ & $\begin{array}{l}\text { Printed gradient color scale from: } \\
\text { yellow, RGB values } 255,221,0 \\
\text { brown, RGB values } 106,60,0\end{array}$ & $\begin{array}{l}1 \\
14\end{array}$ \\
\hline $\begin{array}{l}\text { Fermented } \\
\text { Odor }\end{array}$ & $\begin{array}{l}\text { The degree of fermented odor, described } \\
\text { as a complex combination of cloyingly } \\
\text { sweet, fruity, and musty }\end{array}$ & $\begin{array}{l}\text { Overripe pawpaw pulp that had badly } \\
\text { browned }\end{array}$ & 4 \\
\hline Body & $\begin{array}{l}\text { Mouthfeel sensation associated with the } \\
\text { firmness, cohesiveness, and denseness of } \\
\text { the pulp when compressed between the } \\
\text { tongue and palate. }\end{array}$ & $\begin{array}{l}\text { Applesauce, unsweetened (Great Value } \\
\text { brand) } \\
\text { Creamed Wheat Cereal (Malt O Meal, } \\
\text { prepared according to package, cooled } \\
\text { to room temp.) }\end{array}$ & 1 \\
\hline Sweet & $\begin{array}{l}\text { The amount of sweet taste detected from } \\
\text { the sample as it is being chewed before } \\
\text { being swallowed or expectorated. }\end{array}$ & $\begin{array}{l}\text { Applesauce, unsweetened (Great Value } \\
\text { brand) }\end{array}$ & 4 \\
\hline Sour & $\begin{array}{l}\text { The amount of sour taste detected from } \\
\text { the sample as it is being chewed before } \\
\text { being swallowed or expectorated. }\end{array}$ & $\begin{array}{l}\text { Applesauce, unsweetened (Great Value } \\
\text { brand) }\end{array}$ & 5 \\
\hline Banana & $\begin{array}{l}\text { The amount of banana flavor detected } \\
\text { from the sample as it is being chewed } \\
\text { before being swallowed or expectorated. }\end{array}$ & $\begin{array}{l}\text { Banana pudding (Kroger brand, prepared } \\
\text { according to package) }\end{array}$ & 7.5 \\
\hline Melon & $\begin{array}{l}\text { The amount of melon flavor detected } \\
\text { from the sample as it is being chewed } \\
\text { before being swallowed or expectorated. }\end{array}$ & Honeydew melon, fresh, $1 / 2-1$ inch cube & 8 \\
\hline Mango & $\begin{array}{l}\text { The amount of mango flavor detected } \\
\text { from the sample as it is being chewed } \\
\text { before being swallowed or expectorated. }\end{array}$ & Mango (Del Monte brand, in light syrup) & 8 \\
\hline Papaya & $\begin{array}{l}\text { The amount of papaya flavor detected } \\
\text { from the sample as it is being chewed } \\
\text { before being swallowed or expectorated. }\end{array}$ & Papaya, fresh, $1 / 2-1$ inch strip & 7 \\
\hline Tropical & $\begin{array}{l}\text { The amount of tropical flavor detected } \\
\text { from the sample as it is being chewed } \\
\text { before being swallowed or expectorated. }\end{array}$ & $\begin{array}{l}\text { Papaya chunk (from Dole Tropical Fruit } \\
\text { mix) }\end{array}$ & 9.5 \\
\hline $\begin{array}{l}\text { Bitter } \\
\text { Aftertaste }\end{array}$ & $\begin{array}{l}\text { The amount of bitter aftertaste detected } \\
\text { from the sample after it is chewed and } \\
\text { swallowed or expectorated. }\end{array}$ & $\begin{array}{l}\text { Black tea (Rose brand, steeped for } 1 \text { hour in } \\
\text { hot water) }\end{array}$ & 8 \\
\hline $\begin{array}{l}\text { Rindy } \\
\text { Aftertaste }\end{array}$ & $\begin{array}{l}\text { The amount of rindy aftertaste detected } \\
\text { from the sample after it is chewed and } \\
\text { swallowed or expectorated. }\end{array}$ & Orange rind, served with flesh and rind & 9.5 \\
\hline Astringent & $\begin{array}{l}\text { The amount of astringency on the tongue } \\
\text { and in the mouth detected from the } \\
\text { sample after it is chewed and swallowed } \\
\text { or expectorated. }\end{array}$ & $\begin{array}{l}\text { Black tea (Rose brand, steeped for } 1 \text { hour in } \\
\text { hot water) }\end{array}$ & 6.5 \\
\hline
\end{tabular}

\footnotetext{
${ }^{1}$ Position on $15-\mathrm{cm}$ line scale.

${ }^{2}$ Generated by descriptive analysis panel.

${ }^{3}$ Adapted from Meilgaard et al. (1999).
} 
Table 3. Participant demographics, mean rankings for three tropical fruit purees from a three-way forced choice consumer ranking test, and percentage of participants who correctly identified pawpaw

\begin{tabular}{|c|c|c|c|c|c|c|}
\hline & $\mathrm{n}$ & $\begin{array}{l}279 \\
\text { Papaya }\end{array}$ & $\begin{array}{l}852 \\
\text { Pawpaw }\end{array}$ & $\begin{array}{l}452 \\
\text { Mango }\end{array}$ & $\begin{array}{l}\text { Correct } \\
\text { Identification }\end{array}$ & Pawpaw \\
\hline $\begin{array}{l}\text { Participant } \quad \text { Demographics } \\
\text { Overall }\end{array}$ & 98 & $2.3 \mathrm{a}$ & $2.3 \mathrm{a}$ & $1.4 \mathrm{~b}$ & $9 \%$ & \\
\hline \multicolumn{7}{|l|}{ Gender } \\
\hline Male & $26(27 \%)$ & $2.0 \mathrm{~b}$ & $2.5 \mathrm{a}$ & $1.5 \mathrm{c}$ & $11 \%$ & \\
\hline Female & $72(73 \%)$ & $2.4 \mathrm{a}$ & $2.2 \mathrm{a}$ & $1.4 \mathrm{~b}$ & $8 \%$ & \\
\hline \multicolumn{7}{|l|}{ Age } \\
\hline $18-21$ & $48(49 \%)$ & $2.2 \mathrm{a}$ & $2.4 \mathrm{~b}$ & $1.4 \mathrm{~b}$ & $4 \%$ & \\
\hline Older than 21 & $50(51 \%)$ & $2.4 \mathrm{a}$ & $2.2 \mathrm{a}$ & $1.5 \mathrm{~b}$ & $14 \%$ & \\
\hline \multicolumn{7}{|l|}{ Education } \\
\hline High School & $4(4 \%)$ & $1.8 \mathrm{a}, \mathrm{b}$ & $2.8 \mathrm{~b}$ & $1.5 \mathrm{~b}$ & $0 \%$ & \\
\hline Some College & $60(61 \%)$ & $2.3 \mathrm{a}$ & $2.3 \mathrm{a}$ & $1.4 \mathrm{~b}$ & $3 \%$ & \\
\hline Bachelor's & $20(20 \%)$ & $2.2 \mathrm{a}$ & $2.5 \mathrm{a}$ & $1.4 \mathrm{~b}$ & $10 \%$ & \\
\hline Master's or Ph.D. & $14(14 \%)$ & $2.4 \mathrm{a}$ & $2.0 \mathrm{a}, \mathrm{b}$ & $1.6 \mathrm{~b}$ & $36 \%$ & \\
\hline \multicolumn{7}{|l|}{ Servings of Fruit Consumed per Day } \\
\hline Less than 5 & $86(88 \%)$ & $2.3 \mathrm{a}$ & $2.3 \mathrm{a}$ & $1.4 \mathrm{~b}$ & $8 \%$ & \\
\hline 5 or more & $12(12 \%)$ & $2.3 \mathrm{a}$ & $2.4 \mathrm{a}$ & $1.2 \mathrm{~b}$ & $17 \%$ & \\
\hline \multicolumn{7}{|c|}{ Frequency of Consumption of Tropical Fruit per Week } \\
\hline None & $15(15 \%)$ & $2.5 \mathrm{a}$ & $2.2 \mathrm{a}$ & $1.3 \mathrm{~b}$ & $7 \%$ & \\
\hline $1-3$ & $67(68 \%)$ & $2.3 \mathrm{a}$ & $2.3 \mathrm{a}$ & $1.4 \mathrm{~b}$ & $7 \%$ & \\
\hline More than 4 & $16(16 \%)$ & $2.2 \mathrm{a}, \mathrm{b}$ & $2.3 \mathrm{a}$ & $1.5 \mathrm{~b}$ & $19 \%$ & \\
\hline
\end{tabular}

Table 4. Frequency of fruit puree selected as the favorite (i.e ranked $1^{\text {st }}$ ) compared to the other two fruits in a three-way forced choice consumer ranking test. Correct Identification refers to the percentage of consumers who correctly identified the fruit puree that they ranked as favorite

\begin{tabular}{|l|l|l|}
\hline Fruit & Favorite & Correct Identification \\
\hline Mango & $70 \%$ & $33 \%$ \\
\hline Pawpaw & $16 \%$ & $9 \%$ \\
\hline Papaya & $14 \%$ & $26 \%$ \\
\hline
\end{tabular}


Table 5. P-values for the main effects of month of storage $[0,2,4,6,8,10,12$ ), packaging condition (vacuum, air), and heat treatment (raw, cooked), 2-way interactions, and 3-way interactions on sensory and quality attributes of pawpaw pulp

\begin{tabular}{|l|l|l|l|l|l|l|l|}
\hline & \multicolumn{5}{|l|}{ 2-way Interactions } & 3-way \\
\hline & $\begin{array}{l}\text { Main Effects } \\
\text { Storage } \\
(\text { MONTH) }\end{array}$ & $\begin{array}{l}\text { Packaging } \\
\text { Condition } \\
(\text { PACK) }\end{array}$ & $\begin{array}{l}\text { Heat } \\
\text { Treatment } \\
(\text { HEAT) }\end{array}$ & $\begin{array}{l}\text { MONTH } \\
\text { X PACK }\end{array}$ & $\begin{array}{l}\text { MONTH } \\
\text { X HEAT }\end{array}$ & $\begin{array}{l}\text { PACK X } \\
\text { HEAT }\end{array}$ & $\begin{array}{l}\text { MONTH } \\
\text { PACK X } \\
\text { HEAT }\end{array}$ \\
\hline Color (sensory) & N.S. & N.S. & $<0.001$ & N.S. & N.S. & N.S. & N.S. \\
\hline L* & 0.011 & N.S. & N.S. & 0.001 & $<0.001$ & N.S. & 0.017 \\
\hline a* $^{*}$ & $<0.001$ & $<0.001$ & $<0.001$ & $<0.001$ & $<0.001$ & $<0.001$ & $<0.001$ \\
\hline b $^{*}$ & 0.001 & N.S. & $<0.001$ & 0.001 & $<0.001$ & N.S. & 0.038 \\
\hline Body (sensory) & N.S. & 0.031 & N.S. & N.S. & N.S. & N.S. & N.S. \\
\hline Fermented odor & N.S. & N.S. & N.S. & N.S. & N.S. & N.S. & N.S. \\
\hline Banana flavor & N.S. & N.S. & N.S. & N.S. & N.S. & N.S. & N.S. \\
\hline Melon flavor & N.S. & N.S. & N.S. & N.S. & N.S. & N.S. & N.S. \\
\hline Mango flavor & N.S. & N.S. & N.S. & N.S. & N.S. & N.S. & N.S. \\
\hline Papaya flavor & N.S. & N.S. & N.S. & N.S. & N.S. & N.S. & N.S. \\
\hline Tropical flavor & N.S. & N.S. & N.S. & N.S. & N.S. & N.S. & N.S. \\
\hline Sweet taste & N.S. & N.S. & N.S. & N.S. & N.S. & N.S. & N.S. \\
\hline Sour taste & N.S. & N.S. & N.S. & N.S. & N.S. & N.S. & N.S. \\
\hline Bitter aftertaste & N.S. & N.S. & N.S. & N.S. & N.S. & N.S. & N.S. \\
\hline Rindy aftertaste & N.S. & N.S. & N.S. & N.S. & N.S. & N.S. & N.S. \\
\hline Astringent & N.S. & N.S. & N.S. & N.S. & N.S. & N.S. & N.S. \\
\hline N.S. N & & & & \\
\hline
\end{tabular}

N.S. $=$ Not significant at $\mathrm{p}<0.05$. 
Table 6. Mean values \pm standard deviations of sensory color $(n=4)$, sensory body $(n=4)$, and CIE L*, $a^{*}$, and $b^{*}$ values $(n=6)$ for pawpaw pulp stored frozen raw or heat treated (Cook), and in the absence (vac) or presence (air) of air in the package. Different superscripts within a column denote significant differences at $\mathrm{P}<0.05$

\begin{tabular}{|c|c|c|c|c|c|c|c|c|c|c|c|}
\hline Month & Treatment & \multicolumn{2}{|c|}{ Color } & \multicolumn{2}{|c|}{$\mathrm{L}^{*}$} & \multicolumn{2}{|c|}{$a^{*}$} & \multicolumn{2}{|c|}{$b^{*}$} & \multicolumn{2}{|c|}{ Body } \\
\hline \multirow[t]{4}{*}{0} & Raw vac & 6.3 & \pm 1.8 & $67.9^{\mathrm{a}}$ & \pm 0.1 & $5.4^{\operatorname{lmnop}}$ & \pm 0.6 & $30.0^{\text {efgh }}$ & \pm 1.8 & 5.9 & \pm 1.6 \\
\hline & Raw air & 5.6 & \pm 2.0 & $67.5^{\mathrm{ab}}$ & \pm 0.4 & $7.0^{\mathrm{c}}$ & \pm 0.2 & $33.2^{\text {abcdea }}$ & \pm 0.8 & 5.9 & \pm 1.1 \\
\hline & Cook vac & 5.6 & \pm 0.6 & $53.8^{d}$ & \pm 1.4 & $4.9^{\mathrm{opq}}$ & \pm 0.7 & $33.6^{\text {abcd }}$ & \pm 1.2 & 7.5 & \pm 2.1 \\
\hline & Cook air & 5.6 & \pm 1.8 & $65.5^{\mathrm{abc}}$ & \pm 0.6 & $5.5^{\mathrm{jklmn}}$ & \pm 0.2 & $30.3^{\text {defgh }}$ & \pm 1.1 & 8.1 & \pm 1.8 \\
\hline \multirow[t]{4}{*}{2} & Raw vac & 5.3 & \pm 0.8 & $63.4^{\mathrm{abc}}$ & \pm 1.8 & $6.6^{\text {defg }}$ & \pm 0.1 & $34.5^{\mathrm{ab}}$ & \pm 1.1 & 7.0 & \pm 2.6 \\
\hline & Raw air & 6.5 & \pm 1.0 & $64.8^{\mathrm{abc}}$ & \pm 1.2 & $7.5^{\text {bd }}$ & \pm 0.5 & $32.4^{\text {bcdef }}$ & \pm 2.3 & 6.8 & \pm 3.4 \\
\hline & Cook vac & 5.8 & \pm 0.9 & $65.4^{\mathrm{abc}}$ & \pm 0.7 & $5.2^{\mathrm{mnop}}$ & \pm 0.4 & $32.3^{\text {bcdef }}$ & \pm 1.5 & 7.4 & \pm 1.4 \\
\hline & Cook air & 3.9 & \pm 0.8 & $64.2^{\mathrm{abc}}$ & \pm 0.3 & $5.1^{\text {nop }}$ & \pm 0.5 & $30.6^{\text {cdefgh }}$ & \pm 1.6 & 8.0 & \pm 3.0 \\
\hline \multirow[t]{4}{*}{4} & Raw vac & 5.9 & \pm 1.2 & $66.1^{\mathrm{ab}}$ & \pm 0.3 & $6.9^{\mathrm{de}}$ & \pm 0.1 & $34.6^{\mathrm{ab}}$ & \pm 2.6 & 4.7 & \pm 1.7 \\
\hline & Raw air & 6.1 & \pm 0.7 & $67.6^{\mathrm{ab}}$ & \pm 1.5 & $7.7^{\text {bd }}$ & \pm 0.4 & $35.9^{\mathrm{a}}$ & \pm 0.1 & 7.7 & \pm 2.2 \\
\hline & Cook vac & 5.9 & \pm 1.0 & $68.9^{a}$ & \pm 1.6 & $5.2^{\mathrm{mnop}}$ & \pm 0.2 & $29.6^{\mathrm{fgh}}$ & \pm 0.7 & 6.2 & \pm 2.5 \\
\hline & Cook air & 5.7 & \pm 1.5 & $63.2^{a b c}$ & \pm 0.5 & $6.1^{\text {fghij }}$ & \pm 0.1 & $28.0^{\mathrm{hi}}$ & \pm 1.8 & 6.1 & \pm 1.9 \\
\hline \multirow[t]{4}{*}{6} & Raw vac & 5.9 & \pm 1.7 & $65.3^{\mathrm{abc}}$ & \pm 0.6 & $7.6^{\text {bd }}$ & \pm 0.5 & $34.7^{\mathrm{ab}}$ & \pm 0.6 & 8.3 & \pm 2.5 \\
\hline & Raw air & 6.8 & \pm 1.7 & $62.1^{\mathrm{abc}}$ & \pm 0.3 & $6.7^{\mathrm{def}}$ & \pm 0.5 & $32.3^{\text {bcdef }}$ & \pm 3.1 & 6.8 & \pm 2.8 \\
\hline & Cook vac & 5.5 & \pm 0.9 & $65.6^{\mathrm{abc}}$ & \pm 0.4 & $5.9^{\text {hijkl }}$ & \pm 0.5 & $30.5^{\text {cdefgh }}$ & \pm 2.6 & 5.5 & \pm 1.2 \\
\hline & Cook air & 6.0 & \pm 1.3 & $53.7^{d}$ & \pm 14.7 & $5.5^{\mathrm{klmno}}$ & \pm 0.3 & $31.4^{\text {bcdefg }}$ & \pm 1.3 & 7.0 & \pm 2.4 \\
\hline \multirow[t]{4}{*}{8} & Raw vac & 6.4 & \pm 1.8 & $63.2^{a b c}$ & \pm 1.2 & $6.5^{\text {defgh }}$ & \pm 0.2 & $33.9^{a b c}$ & \pm 1.1 & 6.0 & \pm 1.7 \\
\hline & Raw air & 6.1 & \pm 0.6 & $64.1^{a b c}$ & \pm 0.9 & $7.8^{\mathrm{bd}}$ & \pm 0.5 & $36.2^{\mathrm{a}}$ & \pm 1.2 & 8.5 & \pm 2.5 \\
\hline & Cook vac & 5.0 & \pm 0.7 & $62.0^{a b c}$ & \pm 0.7 & $4.3^{\mathrm{q}}$ & \pm 0.2 & $28.0^{\mathrm{hi}}$ & \pm 2.6 & 5.9 & \pm 1.6 \\
\hline & Cook air & 4.8 & \pm 0.4 & $64.1^{\mathrm{abc}}$ & \pm 1.1 & $5.8^{\mathrm{ijk} k m}$ & \pm 0.4 & $28.3^{\text {ghi }}$ & \pm 2.5 & 7.1 & \pm 2.6 \\
\hline \multirow[t]{4}{*}{10} & Raw vac & 6.0 & \pm 1.0 & $60.7^{b c}$ & \pm 0.3 & $6.0^{\text {hijkl }}$ & \pm 0.2 & $33.5^{\mathrm{abcd}}$ & \pm 1.3 & 5.5 & \pm 2.8 \\
\hline & Raw air & 6.5 & \pm 0.9 & $61.8^{a b c}$ & \pm 0.8 & $7.8^{\mathrm{bd}}$ & \pm 0.5 & $32.5^{\text {bcdef }}$ & \pm 5.1 & 6.9 & \pm 3.2 \\
\hline & Cook vac & 5.2 & \pm 1.5 & $63.4^{\mathrm{abc}}$ & \pm 0.3 & $4.8^{\mathrm{pq}}$ & \pm 0.4 & $30.1^{\text {defgh }}$ & \pm 1.0 & 7.4 & \pm 1.6 \\
\hline & Cook air & 4.5 & \pm 0.5 & $64.3^{a b c}$ & \pm 0.6 & $6.1^{\text {fghij }}$ & \pm 0.2 & $29.9^{\text {efgh }}$ & \pm 2.7 & 7.8 & \pm 2.1 \\
\hline \multirow[t]{4}{*}{12} & Raw vac & 6.5 & \pm 1.5 & $62.2^{\mathrm{abc}}$ & \pm 1.9 & $6.3^{\text {efghi }}$ & \pm 0.6 & $32.3^{\text {bcdef }}$ & \pm 2.9 & 6.0 & \pm 1.7 \\
\hline & Raw air & 7.3 & \pm 0.9 & $58.4^{\mathrm{cd}}$ & \pm 0.7 & $9.6^{\mathrm{a}}$ & \pm 0.4 & $27.5^{\text {hi }}$ & \pm 2.6 & 9.1 & \pm 3.5 \\
\hline & Cook vac & 5.0 & \pm 1.9 & $63.7^{\mathrm{abc}}$ & \pm 0.4 & $5.2^{\text {mnop }}$ & \pm 0.1 & $31.6^{\text {bcdefg }}$ & \pm 0.3 & 5.9 & \pm 1.0 \\
\hline & Cook air & 5.8 & \pm 1.9 & $60.6^{\mathrm{bc}}$ & \pm 1.3 & $6.1^{\text {ghijk }}$ & \pm 0.4 & $26.1^{\mathrm{i}}$ & \pm 1.0 & 6.1 & \pm 2.0 \\
\hline
\end{tabular}


Table 7. Mean values \pm standard deviations of descriptive sensory flavor attributes $(n=4)$ for pawpaw pulp stored frozen raw or heat treated (Cook), and in the absence (vac) or presence (air) of air in the package

\begin{tabular}{|c|c|c|c|c|c|c|c|c|c|c|c|}
\hline Month & Treatment & & nana & & elon & & ango & & paya & & pical \\
\hline \multirow[t]{4}{*}{0} & Raw vac & 5.1 & \pm 1.1 & 4.4 & \pm 2.1 & 5.0 & \pm 2.0 & 4.3 & \pm 1.4 & 2.2 & \pm 1.1 \\
\hline & Raw air & 5.1 & \pm 1.8 & 4.8 & \pm 0.8 & 5.6 & \pm 1.2 & 4.8 & \pm 1.3 & 2.2 & \pm 1.7 \\
\hline & Cook vac & 6.5 & \pm 2.0 & 4.1 & \pm 1.8 & 4.6 & \pm 2.1 & 4.5 & \pm 1.8 & 2.1 & \pm 1.4 \\
\hline & Cook air & 5.0 & \pm 1.5 & 4.6 & \pm 1.3 & 4.5 & \pm 2.0 & 5.1 & \pm 1.3 & 2.1 & \pm 1.2 \\
\hline \multirow[t]{4}{*}{2} & Raw vac & 5.3 & \pm 1.4 & 4.3 & \pm 1.5 & 4.9 & \pm 2.1 & 4.4 & \pm 1.5 & 1.6 & \pm 1.0 \\
\hline & Raw air & 5.1 & \pm 1.7 & 4.5 & \pm 0.9 & 5.6 & \pm 1.4 & 5.0 & \pm 1.1 & 2.7 & \pm 1.2 \\
\hline & Cook vac & 5.9 & \pm 0.9 & 4.3 & \pm 1.9 & 4.5 & \pm 1.9 & 4.7 & \pm 1.1 & 1.9 & \pm 1.2 \\
\hline & Cook air & 6.0 & \pm 0.9 & 5.1 & \pm 1.6 & 5.0 & \pm 1.9 & 5.0 & \pm 0.3 & 2.6 & \pm 1.9 \\
\hline \multirow[t]{4}{*}{4} & Raw vac & 5.5 & \pm 1.1 & 4.3 & \pm 1.9 & 4.1 & \pm 2.0 & 4.4 & \pm 1.6 & 2.0 & \pm 1.0 \\
\hline & Raw air & 5.9 & \pm 0.9 & 4.6 & \pm 1.1 & 4.8 & \pm 1.9 & 5.1 & \pm 1.1 & 2.0 & \pm 1.2 \\
\hline & Cook vac & 4.8 & \pm 1.5 & 5.1 & \pm 1.4 & 4.7 & \pm 2.0 & 4.7 & \pm 1.1 & 2.1 & \pm 1.5 \\
\hline & Cook air & 4.9 & \pm 1.4 & 4.7 & \pm 1.3 & 4.7 & \pm 1.9 & 5.1 & \pm 0.8 & 2.2 & \pm 1.5 \\
\hline \multirow[t]{4}{*}{6} & Raw vac & 5.5 & \pm 1.3 & 4.9 & \pm 1.5 & 4.5 & \pm 1.8 & 5.2 & \pm 0.5 & 3.7 & \pm 2.4 \\
\hline & Raw air & 5.6 & \pm 0.8 & 4.2 & \pm 1.6 & 4.7 & \pm 2.0 & 4.7 & \pm 1.5 & 1.9 & \pm 0.9 \\
\hline & Cook vac & 4.5 & \pm 1.6 & 4.8 & \pm 0.9 & 4.2 & \pm 1.8 & 4.9 & \pm 0.9 & 2.1 & \pm 0.4 \\
\hline & Cook air & 5.5 & \pm 0.6 & 4.4 & \pm 1.4 & 4.8 & \pm 2.2 & 4.2 & \pm 1.9 & 3.5 & \pm 2.5 \\
\hline \multirow[t]{4}{*}{8} & Raw vac & 5.1 & \pm 1.0 & 4.9 & \pm 0.8 & 4.4 & \pm 1.7 & 4.3 & \pm 1.7 & 2.1 & \pm 0.9 \\
\hline & Raw air & 5.3 & \pm 1.1 & 4.9 & \pm 1.7 & 5.0 & \pm 1.6 & 4.7 & \pm 1.2 & 2.3 & \pm 0.9 \\
\hline & Cook vac & 6.0 & \pm 0.5 & 4.2 & \pm 1.1 & 4.8 & \pm 1.9 & 4.8 & \pm 0.6 & 2.1 & \pm 1.2 \\
\hline & Cook air & 4.7 & \pm 0.9 & 3.9 & \pm 1.4 & 4.8 & \pm 1.4 & 4.2 & \pm 1.0 & 2.5 & \pm 1.1 \\
\hline \multirow[t]{4}{*}{10} & Raw vac & 5.0 & \pm 0.8 & 4.3 & \pm 1.5 & 4.5 & \pm 2.0 & 4.4 & \pm 1.2 & 2.0 & \pm 1.0 \\
\hline & Raw air & 5.4 & \pm 1.2 & 4.7 & \pm 1.8 & 4.4 & \pm 1.9 & 4.4 & \pm 1.5 & 3.5 & \pm 2.4 \\
\hline & Cook vac & 5.0 & \pm 0.8 & 4.0 & \pm 1.5 & 4.7 & \pm 2.2 & 4.9 & \pm 0.9 & 1.8 & \pm 1.3 \\
\hline & Cook air & 5.6 & \pm 1.0 & 4.7 & \pm 1.3 & 5.0 & \pm 1.3 & 4.5 & \pm 0.4 & 2.4 & \pm 0.8 \\
\hline \multirow[t]{4}{*}{12} & Raw vac & 4.7 & \pm 1.6 & 3.9 & \pm 1.5 & 4.7 & \pm 0.9 & 4.6 & \pm 0.7 & 2.6 & \pm 1.1 \\
\hline & Raw air & 5.5 & \pm 1.1 & 4.7 & \pm 1.2 & 4.6 & \pm 1.3 & 4.4 & \pm 0.5 & 2.1 & \pm 1.2 \\
\hline & Cook vac & 5.1 & \pm 1.5 & 4.4 & \pm 1.8 & 5.0 & \pm 1.2 & 4.8 & \pm 0.9 & 1.9 & \pm 1.1 \\
\hline & Cook air & 4.8 & \pm 1.4 & 4.2 & \pm 1.5 & 5.2 & \pm 0.9 & 4.9 & \pm 1.1 & 2.7 & \pm 1.2 \\
\hline
\end{tabular}


Table 8. Mean values \pm standard deviations of descriptive sensory attributes $(n=4)$ for pawpaw pulp stored frozen raw or heat treated (Cook), and in the absence (vac) or presence (air) of air in the package

\begin{tabular}{|c|c|c|c|c|c|c|c|c|c|c|c|c|c|}
\hline Month & Treatment & $\begin{array}{l}\text { Fern } \\
\text { Odo }\end{array}$ & ented & $\begin{array}{l}\text { Swe } \\
\text { Tas }\end{array}$ & & $\begin{array}{l}\text { Sou } \\
\text { Tast }\end{array}$ & & $\begin{array}{l}\text { Bitt } \\
\text { Aft }\end{array}$ & & $\begin{array}{l}\text { Rinc } \\
\text { Afte }\end{array}$ & & Astr & ngent \\
\hline \multirow[t]{4}{*}{0} & Raw vac & 1.2 & \pm 0.4 & 5.2 & \pm 3.2 & 3.2 & \pm 1.3 & 4.8 & \pm 0.5 & 2.7 & \pm 1.6 & 3.4 & \pm 0.8 \\
\hline & Raw air & 0.7 & \pm 0.4 & 5.1 & \pm 0.5 & 3.3 & \pm 0.6 & 5.4 & \pm 0.8 & 2.6 & \pm 1.5 & 3.4 & \pm 0.7 \\
\hline & Cook vac & 1.5 & \pm 0.7 & 5.2 & \pm 1.4 & 3.3 & \pm 2.3 & 5.4 & \pm 1.9 & 2.9 & \pm 1.5 & 3.7 & \pm 0.5 \\
\hline & Cook air & 1.1 & \pm 0.7 & 4.6 & \pm 1.9 & 2.8 & \pm 1.1 & 4.3 & \pm 0.7 & 2.3 & \pm 1.0 & 2.7 & \pm 1.2 \\
\hline \multirow[t]{4}{*}{2} & Raw vac & 1.5 & \pm 0.9 & 4.9 & \pm 0.5 & 3.0 & \pm 1.0 & 5.7 & \pm 1.1 & 2.9 & \pm 1.9 & 4.0 & \pm 1.0 \\
\hline & Raw air & 1.3 & \pm 0.8 & 4.6 & \pm 1.6 & 2.8 & \pm 0.5 & 5.9 & \pm 0.4 & 3.2 & \pm 1.8 & 4.0 & \pm 0.4 \\
\hline & Cook vac & 1.0 & \pm 0.7 & 4.9 & \pm 0.9 & 3.6 & \pm 1.3 & 5.8 & \pm 0.6 & 2.8 & \pm 1.8 & 3.4 & \pm 1.1 \\
\hline & Cook air & 1.2 & \pm 0.8 & 5.3 & \pm 1.4 & 3.5 & \pm 2.9 & 5.0 & \pm 0.4 & 3.4 & \pm 1.8 & 3.6 & \pm 1.4 \\
\hline \multirow[t]{4}{*}{4} & Raw vac & 1.6 & \pm 0.9 & 5.3 & \pm 0.8 & 2.9 & \pm 1.8 & 4.9 & \pm 1.3 & 2.1 & \pm 1.3 & 3.3 & \pm 0.7 \\
\hline & Raw air & 1.3 & \pm 0.5 & 5.6 & \pm 1.1 & 3.6 & \pm 1.3 & 5.3 & \pm 0.8 & 3.1 & \pm 1.9 & 3.6 & \pm 1.0 \\
\hline & Cook vac & 1.1 & \pm 0.9 & 4.6 & \pm 1.6 & 3.2 & \pm 1.0 & 4.6 & \pm 0.9 & 2.2 & \pm 1.8 & 2.9 & \pm 1.0 \\
\hline & Cook air & 1.0 & \pm 0.4 & 4.4 & \pm 0.8 & 3.1 & \pm 1.7 & 6.0 & \pm 1.3 & 2.9 & \pm 2.1 & 3.7 & \pm 0.9 \\
\hline \multirow[t]{4}{*}{6} & Raw vac & 1.0 & \pm 0.9 & 4.9 & \pm 1.2 & 3.4 & \pm 2.2 & 4.7 & \pm 1.0 & 2.6 & \pm 1.5 & 3.0 & \pm 1.2 \\
\hline & Raw air & 1.3 & \pm 0.4 & 4.8 & \pm 2.4 & 4.0 & \pm 2.5 & 5.5 & \pm 2.5 & 2.9 & \pm 1.7 & 4.0 & \pm 2.1 \\
\hline & Cook vac & 1.1 & \pm 0.8 & 4.9 & \pm 0.5 & 3.0 & \pm 1.5 & 5.3 & \pm 1.7 & 2.4 & \pm 1.3 & 3.8 & \pm 1.3 \\
\hline & Cook air & 1.2 & \pm 1.1 & 4.6 & \pm 1.1 & 3.7 & \pm 1.2 & 5.2 & \pm 0.7 & 2.9 & \pm 1.7 & 3.1 & \pm 0.8 \\
\hline \multirow[t]{4}{*}{8} & Raw vac & 0.9 & \pm 0.8 & 5.8 & \pm 2.6 & 2.7 & \pm 1.7 & 5.5 & \pm 0.8 & 2.9 & \pm 1.9 & 3.5 & \pm 1.1 \\
\hline & Raw air & 1.0 & \pm 0.6 & 5.7 & \pm 1.5 & 3.1 & \pm 1.7 & 5.4 & \pm 1.7 & 2.4 & \pm 1.7 & 3.6 & \pm 0.9 \\
\hline & Cook vac & 1.5 & \pm 1.1 & 4.5 & \pm 1.1 & 2.9 & \pm 1.0 & 5.9 & \pm 0.3 & 3.1 & \pm 1.8 & 3.5 & \pm 0.8 \\
\hline & Cook air & 0.9 & \pm 0.6 & 5.0 & \pm 1.5 & 3.0 & \pm 1.0 & 5.3 & \pm 2.2 & 2.4 & \pm 1.4 & 3.6 & \pm 1.6 \\
\hline \multirow[t]{4}{*}{10} & Raw vac & 1.0 & \pm 0.2 & 5.1 & \pm 0.8 & 2.4 & \pm 0.6 & 5.6 & \pm 2.0 & 3.3 & \pm 1.6 & 3.7 & \pm 0.8 \\
\hline & Raw air & 1.4 & \pm 1.5 & 4.9 & \pm 2.8 & 3.3 & \pm 1.4 & 5.6 & \pm 1.2 & 2.4 & \pm 1.8 & 3.9 & \pm 1.1 \\
\hline & Cook vac & 1.1 & \pm 0.8 & 4.3 & \pm 2.2 & 2.3 & \pm 0.7 & 4.8 & \pm 1.4 & 2.6 & \pm 1.5 & 3.3 & \pm 0.8 \\
\hline & Cook air & 1.5 & \pm 1.0 & 4.5 & \pm 2.1 & 2.8 & \pm 0.8 & 5.4 & \pm 0.6 & 3.2 & \pm 1.8 & 3.4 & \pm 1.1 \\
\hline \multirow[t]{4}{*}{12} & Raw vac & 1.1 & \pm 0.5 & 4.6 & \pm 1.4 & 3.1 & \pm 0.9 & 5.5 & \pm 0.7 & 2.7 & \pm 1.8 & 3.7 & \pm 0.9 \\
\hline & Raw air & 1.4 & \pm 0.9 & 4.2 & \pm 1.8 & 2.4 & \pm 0.9 & 4.6 & \pm 0.5 & 3.1 & \pm 1.7 & 3.7 & \pm 0.5 \\
\hline & Cook vac & 0.7 & \pm 0.4 & 5.3 & \pm 2.8 & 2.3 & \pm 1.2 & 4.6 & \pm 1.1 & 2.3 & \pm 1.0 & 3.6 & \pm 0.9 \\
\hline & Cook air & 0.9 & \pm 0.8 & 4.2 & \pm 1.2 & 3.8 & \pm 1.0 & 6.0 & \pm 1.5 & 2.8 & \pm 1.9 & 4.4 & \pm 0.8 \\
\hline
\end{tabular}



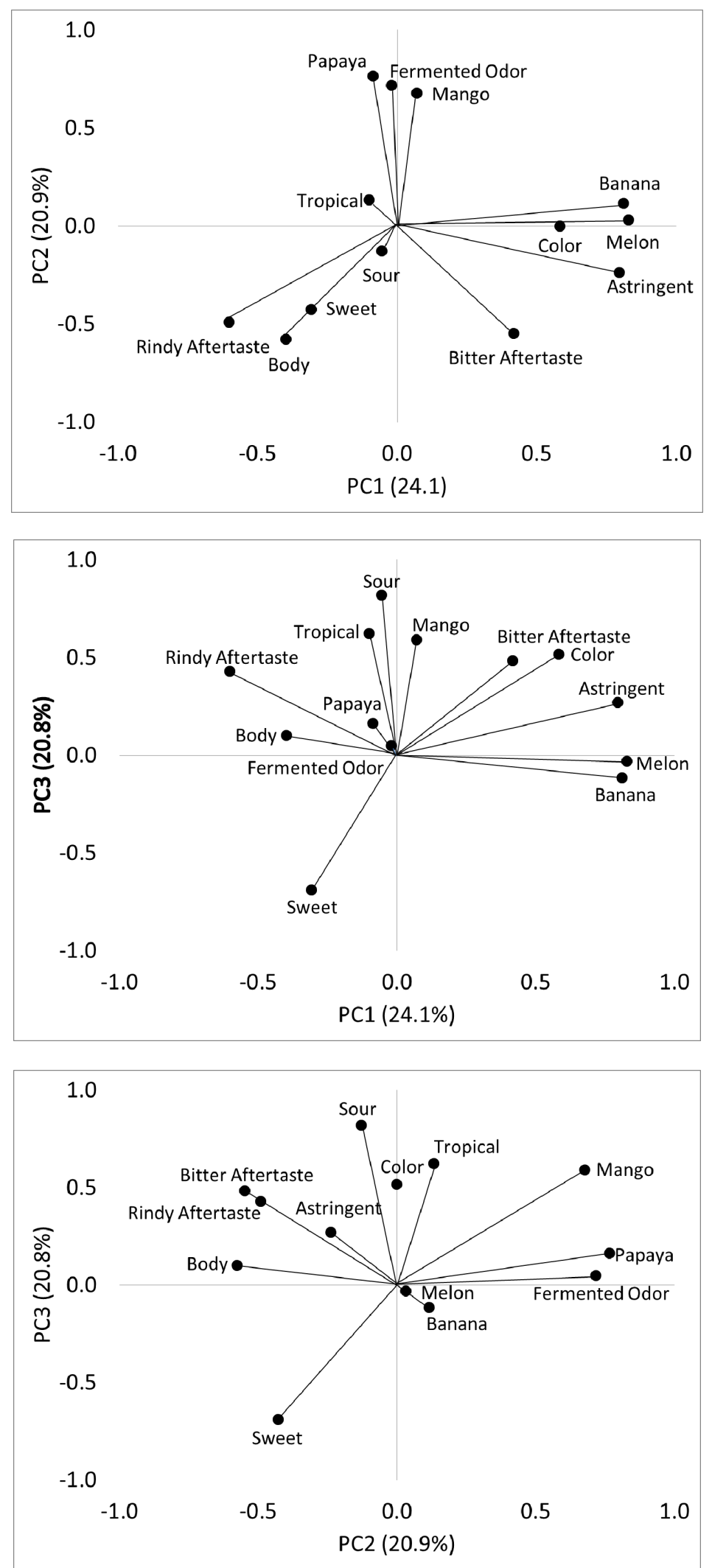

Figure 1. Principal component analysis showing correlations between factor loadings and the three factors for descriptive sensory analysis of pawpaw pulp. The percent of variance explained by each factor is shown in parenthesis 